1 Chemical Profiling of Antimicrobial Metabolites from Halophilic Actinomycete Nocardiopsis_sp. Al-H10-1

2 (KF384482) Isolated from Alang, Gulf of Khambhat, India

$3 \quad$ Nisha Trivedi ${ }^{1}$ and Jignasha Thumar ${ }^{2}$

$4 \quad{ }^{1}$ Department of Microbiology, School of Science, RK University, Rajkot 360020, Gujarat, India.

$5 \quad 2$ Department of Microbiology, Government Science College, Gandhinagar-382015, Gujarat, India.

6 Corresponding Author:

7 Jignasha T. Thumar, Ph. D.

8 Assistant Professor (GES Class II),

9 Department of Microbiology,

10 Government Science College,

11 Sector-15, Gandhinagar-382015, Gujarat, India.

12 E-mail: jignashathumar@gmail.com

13

14 ORCID ID:

15 Nisha Trivedi: https://orcid.org/0000-0003-1425-5007

16 Dr. Jignasha Thumar: https://orcid.org/0000-0002-4732-6759

\title{
17 ACKNOWLEDGEMENT
}

18 Financial Assistance from the Department of Biotechnology (New Delhi, India) is acknowledged.

19 Declarations:

20 Funding: This research was supported by the Department of Biotechnology (New Delhi, India)

21 Conflicts of interest: The authors declare no conflict of interest.

22 Availability of data and material: Not applicable

23 Code availability: Not applicable 


\section{ABSTRACT}

The overuse of antibiotics has resulted in the development of drug resistant, a major problem in disease curing processes i.e. development of drug resistance. The World Health Organization (WHO) released its first list of the most concerning pathogens for human health in 2017 which suggested that there are total 12 bacterial families which have developed multiple drug resistance and for which novel antibiotics are required immediately (WHO 2017). There is a requirement to explore some novel compounds to overcome this issue. Thus our study aimed at exploration of marine actinomycetes as a valuable resource for novel products with antimicrobial properties. The halophilic actinomycete Nocardiopsis_sp. Al-H10-1 (KF384482) was isolated from saline water (20 m away from shore) of Alang coast (Gulf of Khambhat), Bhavnagar, Gujarat, India. The isolate Al-H10-1 was identified as Nocardiopsis sp. through rigorous morphological and cultural characteristics; the species was confirmed through 16s rRNA phylogenetic analysis. The antimicrobial potential of Nocardiopsis sp. Al-H10-1 was assessed against a range of Gram-positive and Gram-negative bacteria as well as three fungi, there it demonstrated antimicrobial activity against four Gram negative bacteria and one Gram positive bacteria. Further active antimicrobial compounds present

42 in ethyl acetate extract was identified using Gas Chromatography-Mass Spectroscopy (GC-MS). GC-MS analysis

43 showed the presence of 17 compounds which included antimicrobial compounds like 2, 4-bis (1, 1-dimethylethyl)-

44 Phenol, Dibutyl phthalate as well as various types of alkanes and their derivatives.

45 Keywords: marine actinomycetes; halophilic; antimicrobial activity; gas chromatography-mass spectroscopy; 2,4bis (1,1-dimethylethyl)-Phenol; Dibutyl phthalate

47 


\section{INTRODUCTION}

The World Health Organization (WHO) released its first list of the most concerning pathogens for human health in 2017 which suggested that there are total 12 bacterial families who have developed multiple drug resistance and for which novel antibiotics are required immediately (WHO, 2017). The study by O'Neill suggests that every year approximately 7,00,000 people die because of drug resistant infections globally and if current trends continue, it will be increased by 10 million people per year by 2050 (O’Neill J, 2016). The multiple drug resistance can be developed in organisms by various types of mechanisms such as presence of antibiotic degrading enzymes, antibiotic altering enzymes, gene transfer processes like conjugation, transformation, transduction etc. So there is a need for searching naturally occurring novel antimicrobial compounds.

The natural products and microbial metabolites are used as the main bioactive scaffold for the development of the novel antibiotics instead of using the large synthetic combinatorial libraries of molecules to develop novel drugs (Challinor VL and Bode HB, 2015). During 1981 to 2014, total 1211 small molecule drugs were approved by the United States Food and Drug Administration (FDA), from which approximately 65\% was accounted for chemicals produced in nature, or compounds based on them (Newman DJ and Cragg GM, 2016). Actinomycetes have always been known as the biotechnologically and industrially important group of microorganisms as they are the great producers of many primary and secondary metabolites useful in a variety of fields including healthcare, agriculture, veterinary etc. (Barka EA et. al., 2016). Various unexplored or underexplored ecosystems are the most promising source of novel actinomycetes able to produce large numbers of secondary metabolites (Dhakal D et. al., 2016; Subramani R and Aalbersberg W, 2013).

The Gulf of Khambhat is a coastal region situated in the Bhavnagar District of the Gujarat State of India. The uniqueness of this region is, its salinity and alkalinity which harbors various unidentified, unique haloalkaliphilic bacterial species which can produce valuable secondary metabolites. Alang is a small town located on the Gulf of Khambhat, considered as the world's largest graveyard of ships. It is well known for its ship breaking and recycling activities, because of which it is also known as the most polluted coastal region (Patel AB et. al., 2018).

\section{MATERIALS AND METHODS}

\section{Isolation}

The halophilic actinomycete, Nocardiopsis_sp. Al-H10-1 was isolated from saline water (20 m away from shore) of Alang coast (Gulf of Khambhat), Bhavnagar, Gujarat, India. The water sample was filtered with whatman filter paper to remove fine soil particles and the filtrate was serially diluted. From the highest dilution containing tube, 0.1 $\mathrm{ml}$ of the sample was spreaded separately on starch agar, starch casein agar and actinomycetes isolation agar (HiMedia, India), containing 5- $10 \% \mathrm{w} / \mathrm{v} \mathrm{NaCl}$. The plates were incubated at $30^{\circ} \mathrm{C}$; on sixth day a typical chalky white colony was picked up and re-streaked on starch agar slants supplemented with $10 \% \mathrm{w} / \mathrm{v} \mathrm{NaCl}$ to ensure the purity of the colony (Chakrabarti T, 1998). The culture was maintained at $4{ }^{\circ} \mathrm{C}$. 
Morphological, physiological and biochemical characteristics of the isolate were determined using standard methods. The morphological characteristics were determined by growing the isolate on a starch agar plate (with $10 \%$ $\mathrm{NaCl})$. After seven days of incubation, the colony characteristics were noted and Gram's staining was performed. Basic biochemical tests were performed for primary characterization of the isolate based on Bergey's manual of systematic Bacteriology Vol. IV (Garrity GM et. al., 2004), which included including carbon sources utilization (Mannitol, Sucrose, Xylose, Glucose, Maltose, and Lactose), Methyl red test, Voges-Proskauer test, $\mathrm{H}_{2} \mathrm{~S}$ production, Catalase test, Indole production, Citrate utilization, Starch hydrolysis, Casein hydrolysis, Gelatin hydrolysis, Nitrate reduction, Urea hydrolysis, Ammonia production, and Triple sugar iron test. All media and test reagents were prepared as mentioned by Cappuccino JG and Sherman N (2004). Antibiotic susceptibility and resistance pattern of the isolate were checked by disc diffusion method (Kumar PS et. al., 2014). The test was conducted against total 13 antibiotics using Starch agar plates with $10 \% \mathrm{NaCl}$.

\section{Molecular Identification of Isolate by 16S rRNA}

The molecular identification of the isolate Al-H10-1 was carried out by 16S rRNA gene sequencing. The 16S rRNA gene was amplified using universal primers 518F 5'ccagcagccgcggtaatacg3' and 800R 5'taccagggtatctaatc3'. PCR products were purified and sequenced. The resultant sequences aligned within the NCBI database (National Centre for Biotechnology Information) using BLASTN. The phylogenetic tree was constructed using neighbor-joining with Kimura 2-state parameter and pairwise-deletion model analysis implemented in the program MEGA software version X (Kumar S et. al., 2018) and also evaluated further in a bootstrap analysis of 1,000 replicates. The 16S rRNA gene sequence of the isolate has been submitted to NCBI, GenBank, Maryland, USA.

The Antimicrobial Potential

114 Antimicrobial activity of Nocardiopsis_sp. Al-H10-1 was checked by spot inoculation method (Kumar N et. al., 2010) using starch agar $(10 \% \mathrm{w} / \mathrm{v} \mathrm{NaCl})$. The spore suspension of the isolate was spotted on the medium and incubated at $28^{\circ} \mathrm{C}$ until sporulation. The test organisms, procured from MTCC, Chandigarh (ATCC equivalent), were used to check antimicrobial activity. These included Gram-positive organisms: Bacillus subtilis, Staphylococcus aureus, Micrococcus luteus, Staphylococcus epidermidis, Bacillus megaterium, Bacillus cereus; Gram-negative organisms: Pseudomonas aeruginosa, Escherichia coli, Enterobacter aerogenes, Serratia marcescens, Shigella flexneri, Salmonella enteric typhimurium, Proteus vulgaris, Klebsiella pneumonia and fungi: Aspergillus niger, Fusarium oxysporum, Candida albicans. The test organisms were grown in nutrient broth at $37^{\circ} \mathrm{C}$

122 for 24 hours. The molten nutrient agar, with $1 \%$ activated test culture, was poured on the sporulated

123 Nocardiopsis_sp. Al-H10-1. After the incubation of 24 hours at $37^{\circ} \mathrm{C}$, the zone of inhibition was measured for each 124 test organism.

\section{Optimization of Growth Conditions for Antimicrobial Compound Production}

126 To achieve the highest production of antimicrobial compounds, effect of various growth conditions were studied by

127 the one variable at a time (OVAT) method. To find out the optimized medium for the growth of the organism as well as for antimicrobial compounds production, the spore suspension of Nocardiopsis_sp. Al-H10-1 was inoculated 
into various flask containing $20 \mathrm{ml}$ of starch broth, with respective starch concentration, $\mathrm{NaCl}$ concentrations and $\mathrm{pH}$ value separately. All the flasks were incubated at $30^{\circ} \mathrm{C}$ for $7-8$ days. Then the cell free filtrates of the culture were collected from all the media separately and were tested against the actively growing sensitive culture of Serratia marcescens by agar well diffusion method. The plates were incubated at $37^{\circ} \mathrm{C}$ for 24 hours followed by the measurement of zone of inhibition. The effect of starch as a carbon source on the growth and antimicrobial compound production was checked by using starch broth supplemented with various concentrations of starch $(0,0.5$, 1 and $1.5 \%), 10 \% \mathrm{NaCl}$. The effect of the salt concentration on growth and the antimicrobial compound production was studied by using $1 \%$ starch broth provided with varying salt concentrations $(0,5,10$ and $15 \% \mathrm{w} / \mathrm{v} \mathrm{NaCl})$. The effect of $\mathrm{pH}$ on growth and antimicrobial compound production was studied by using $1 \%$ starch broth supplemented with $10 \% \mathrm{w} / \mathrm{v} \mathrm{NaCl}$ and the range of $\mathrm{pH}(8,9,10$ and 11).

\section{Extraction of Antimicrobial Metabolites}

140 The strain Nocardiopsis_sp. Al-H10-1 was cultivated in starch broth with $10 \% \mathrm{NaCl}$ on a rotary shaker (120 rpm) at

$14137^{\circ} \mathrm{C}$ for 8 days. The cell-free extract was obtained by filtration of broth culture using Whatman No. 1 filter paper.

142 Equal volume of ethyl acetate was added to the culture filtrate for the extraction of the bioactive compounds. The mixture was added to $250 \mathrm{ml}$ glass flask, sealed with cotton plug, followed by aluminum foil to reduce evaporation of the organic solvent and placed on shaker for 2 hours at $150 \mathrm{rpm}$. Post agitation the mixture was transferred to a separating funnel to generate different layers; the organic layer that contained the secondary metabolites and the aqueous layer. The crude extract was obtained by concentrating the solvent by evaporation and stored at $4{ }^{\circ} \mathrm{C}$ for further use.

Identification of Antimicrobial Metabolites by Using Gas Chromatography-Mass Spectrometry (GC-MS) Analysis Identification of the chemical compounds present in the crude ethyl acetate extract of Nocardiopsis_sp. Al-H10-1 was carried out by Gas Chromatography-Mass Spectrometry (GC-MS) analysis. Analysis was conducted on a capillary column (Rxi-5ms, 30m, $0.25 \mathrm{~mm}$ id, $0.25 \mu \mathrm{m}$ film thickness) with the following conditions: constant flow of Helium, $1.0 \mathrm{ml} \mathrm{min}-1$; the fixed inlet temperature, $285^{\circ} \mathrm{C}$ throughout the analysis; injection volume, $3 \mu \mathrm{l}$ in the linear with an open purge valve (30:1 split ratio); Linear velocity: $36.8 \mathrm{~cm} / \mathrm{sec}$; Pressure: $65.0 \mathrm{kPa}$; Purge flow: 3.5 $\mathrm{ml} / \mathrm{min}$; Column flow: $1 \mathrm{ml} / \mathrm{min}$; Oven ramp: $80{ }^{\circ} \mathrm{C}$ holds for $2.0 \mathrm{~min}, 18{ }^{\circ} \mathrm{C} / \mathrm{min}$ to $260{ }^{\circ} \mathrm{C}$ holds for $6.0 \mathrm{~min}, 4$ ${ }^{\circ} \mathrm{C}$; Interface temperature: $300{ }^{\circ} \mathrm{C}$; Solvent cut time: $5.0 \mathrm{~min}$; Detector voltage: $1 \mathrm{kV}$; Acquisition mode: Scan mode;

157 Scan speed: 909; Event time: $0.78 \mathrm{sec}$; Starting m/z: 40 to $700 \mathrm{~m} / \mathrm{z}$. The peaks were identified by comparing the mass spectra with the National Institute of Standards and Technology (NIST, USA) library.

\section{RESULTS}

\section{Isolation and Morphology of the Organism}

161 Nocardiopsis_sp. Al-H10-1, a halophilic actinomycete was isolated from the site 20m away from Alang sea shore, 162 Gulf of Khambhat, Western India. The isolate was characterized on the basis of its cell and colony morphology and 163 Gram's reaction. The colonies were medium sized, irregular shaped, irregular, slightly raised, rough, and opaque 
with creamy white pigmentation. It was Gram-positive, having a filamentous, long thread-like structure. It started sporulation on starch casein agar after 3 days of incubation with a fluffy mass of spores.

\section{Biochemical Characteristics and Antibiotic Susceptibility Test}

Nocardiopsis_sp. Al-H10-1 is a Gram-positive, filamentous and sporulating organism. Various biochemical tests were performed for primary characterization of the isolate. Nocardiopsis_sp. Al-H10-1 showed positive results for

169 Voges-Proskauer test, Ammonia production, Catalase test, Citrate utilization, Triple sugar iron test, Starch

170 hydrolysis, Casein hydrolysis and Gelatin hydrolysis while organism showed negative results for Methyl red test,

171 Indole production, Urea hydrolysis test, Nitrate reduction test and $\mathrm{H}_{2} \mathrm{~S}$ production. The organism was grown in

172 broth, supplemented with various carbohydrates like Mannitol, Sucrose, Xylose, Glucose, Maltose and Lactose to

173 check its ability to utilize various carbohydrates and their fermentation pattern. Among the six provided

174 carbohydrates, the organism was able to ferment glucose, sucrose, and maltose but not mannitol, xylose and lactose.

175 The results of antibiotic susceptibility test showed that the isolate showed the highest sensitivity towards Rifampicin

176 followed by Vancomycin, Ciprofloxacin, Gentamicin, Chloramphenicol, Streptomycin, Tetracycline, Kanamycin,

177 Penicillin and Polymyxin-13 while the isolate was resistant towards Nalidixic acid, Ampicillin and Methicillin

178 (Table 1).

179 Molecular Identification of Nocardiopsis_sp. Al-H10-1 through 16S rRNA Sequencing

180 The 16S rRNA gene sequencing of the strain Nocardiopsis_sp. Al-H10-1 showed the presence of 1457 bp long 16S

181 rRNA gene in the genomic sequence. The sequence was submitted to NCBI, GenBank, Maryland, USA with

182 accession number (KF384482). The phylogenetic tree was constructed using neighbor-joining with Kimura 2-state

183 parameter and pairwise-deletion model analysis implemented in the program MEGA software version X (Kumar S

184 et. al., 2018) and also evaluated further in a bootstrap analysis of 1,000 replicates (Figure 1). The molecular

185 characterization through $16 \mathrm{~S}$ rRNA gene sequencing revealed the organism belonging to Nocardiopsis $s p$.

\section{The Antimicrobial Potential}

187 The antimicrobial potential of the isolate was checked against six Gram-positive, eight Gram-negative bacteria and 188 three fungi. The isolate Nocardiopsis_sp. Al-H10-1 inhibited the growth of the total five test organisms including four Gram negative bacteria Pseudomonas aeruginosa, Serratia marcescens, Enterobacter aerogenes, Klebsiella pneumonia and one Gram positive bacterium Bacillus megaterium was inhibited (Figure 2). The highest inhibition

191 was recorded against Serratia marcescens, however the isolate didn't show any inhibitory effect against any of the 192 fungi tested for the same.

\section{Optimization of Growth Conditions for Antimicrobial Compound Production}

194 To achieve the highest production of antimicrobial compounds, effect of various growth conditions were studied.

195 Optimization of various growth conditions showed that the highest antimicrobial compound production was 196 obtained in the presence of $0.5 \%$ starch, $10 \% \mathrm{NaCl}$ and pH 9 (Figure 3-5). 
Identification of the bioactive compounds, present in ethyl acetate extract, was carried out using GC-MS analysis. The GC-MS chromatogram of the Nocardiopsis_sp. Al-H10-1 crude extract showed a total of 17 peaks (Figure 6). When compared with the NIST database, the nearest compound hits for those peaks were found (Table 2).

\section{DISCUSSION}

202 From 2007 to 2017 (the duration of 10 years), total 177 new species of rare actinomycetes were reported from the marine habitats representing 33 families from which 3 were novel families and 29 novel genera (Subramani R and

204 Sipkema D, 2019). The study of Berdy J, 2012 suggested that there are approximately 500,000 naturally occurring 205 biological compounds, from which approximately 70,000 are microbially-derived with $29 \%$ is exclusively derived 206 from actinomycetes. Marine actinomycetes are the prominent source of enzymes which can be produced on a large 207 scale and can be used in various industries, such as proteases, cellulases, chitinases, amylases, xylanases, and other enzymes (Vaijayanthi G et. al., 2016). They are also known as the most valuable source of naturally occurring novel antimicrobial compounds (Fiedler Forsyth MP et. al., 1971; Hassanshahian M and Mohamadian J, 2011). So we focused on halophilic actinomycetes for the production of novel antimicrobial compounds in our research. Nocardiopsis_sp. Al-H10-1 was successfully isolated from the marine water sample from Alang sea shore using selective media supplemented with $10 \% \mathrm{NaCl}$. On the basis of morphological and molecular characterization, the 213 isolate was identified as Gram-positive, filamentous, long thread-like structure containing Nocardiopsis_sp. Al-H10-

2141 able to inhibit the growth of four Gram negative bacteria including Pseudomonas aeruginosa, Serratia marcescens, Enterobacter aerogenes, Klebsiella pneumonia and one Gram positive bacterium Bacillus megaterium. Das R et. al. (2018) isolated total 172 actinobacteria using soil samples collected from two microbiologically unexplored forest ecosystems, located in the Eastern Himalayan Biodiversity hotspot region i.e. Nameri National Park (NNP) and Panidehing Wildlife Sanctuary (PWS) by using the same isolation techniques used by us, they further screened 24 strong antimicrobial activity showing isolates using the same spot inoculation method. Biochemical tests of Nocardiopsis_sp. Al-H10-1 showed that the isolate is able to utilize various carbon sources like glucose, citrate, starch, sucrose and maltose; and nitrogen sources like casein and gelatin with production of ammonia. The organism is also able to produce various industrially important enzymes including amylase, proteases like caseinase and gelatinase. The isolate was able to produce catalase which indicates the organism is aerobic in nature. The organism was able to ferment various carbohydrates like glucose, sucrose, and maltose. The negative results for $\mathrm{H}_{2} \mathrm{~S}$ production and nitrate reduction test indicated that the isolate is not able to utilize more complex protein contents and sulfur containing amino acids from the surrounding habitats. Antibiotic sensitivity/resistant profiling is widely used to study microbial diversity in combination with biochemical and molecular characterization of the isolates (Litzner BR et. al., 2006). The antibiotic sensitivity/resistant profiling showed that the isolate is sensitive towards range of protein synthesis inhibiting antibiotics such as chloramphenicol, gentamycin, streptomycin and tetracycline. The highest sensitivity showed towards RNA synthesis inhibiting rifampicin followed by cell wall synthesis inhibiting vancomycin while the isolate showed resistance towards DNA synthesis inhibitor nalidixic acid and cell wall synthesis inhibitors ampicillin and methicillin. The phylogenetic analysis of the isolate showed that Nocardiopsis_sp. Al-H10-1 showed the highest similarity with Nocardiopsis halotolerans DSM44410 strain NBRC100347 (98.63\%) and the lowest similarity with Actinoallomurus acanthiterrae strain 2614A723 
(91.59\%). The antimicrobial compounds produced by Nocardiopsis_sp. Al-H10-1 were extracted by using ethyl acetate (1:1 v/v) from filtrate broth. Charousová I et. al., 2019 also extracted the antimicrobial compounds produced by selected actinomycetes isolated using aridic soil sample collected from Karoo, South Africa. Identification of the bioactive compounds, present in ethyl acetate extract, was carried out using GC-MS analysis. The GC-MS chromatogram of the Nocardiopsis_sp. Al-H10-1 crude extract showed a total of 17 peaks. When compared with the NIST database, the nearest compound hits for those peaks were found. GC-MS analysis indicated the presence of 16 compounds including alkanes (Tetradecane, Pentadecane, Heptadecane, Octadecane, Henicosane, Pentatriacontane); alkenes (Heptadec-1-ene); triterpene (Squalene); phenol (2,4-bis(1,1-dimethylethyl)- Phenol); Dibutyl phthalate; Dodecane- 2-methyl-; Heptadecyl heptafluorobutyrate; Benzenepropanoic acid, 3,5-bis(1,1-dimethylethyl-4-

ester;

8-methyl-heptadecane;

Diethyl-heptoxy-octadecoxysilane;

Pentacyclo[19.3.1.1(3,7).1(9,13).1(15,19)]octa. From 16 identified compounds, 10 compounds have already been reported to have antimicrobial activity (Girija S et. al., 2014; Nandhini SU et. al., 2015; Yogeswari S et. al., 2012; Rahbar N et. al., 2012; Nazemi M et. al., 2010; Roy RN et. al., 2006; Zhang H et. al., 2018; Nithya TG et. al., 1972; Sermakkani M and Thangapandian V, 2012). El-Naggar NE et. al., 2017 also reported presence of alkanes in the ethyl acetate extract of Streptomyces anulatus NEAE-94 using GC-MS analysis.

\section{REFERENCES}

1. Barka EA, Vatsa P, Sanchez L, Gaveau-Vaillant N, Jacquard C, Klenk HP, Clément C, Ouhdouch Y and van Wezel GP (2016). Taxonomy, physiology, and natural products of Actinobacteria. Microbiol. Mol. Biol. Rev., 80, 1-43.

2. Berdy J (2012). Thoughts and facts about antibiotics: Where we are now and where we are heading. J. Antibiot., 65, 385-395.

3. Cappuccino JG and Sherman N (2004) Microbiology, a laboratory manual, 6th edn. Pearson education, Singapore

4. Chakrabarti T (1998). ACTINOMYCETES - Isolation, Screening, Identification, and Gene Cloning in Streptomyces Laboratory manual.

5. Challinor VL and Bode HB (2015). Bioactive natural products from novel microbial sources. Ann. N. Y. Acad. Sci., 1354, 82-97.

6. Charousová I, Medo J, Hleba L, Císarová M and Javoreková S (2019). Antimicrobial activity of actinomycetes and characterization of actinomycin-producing strain KRG-1 isolated from Karoo, South Africa. Brazilian Journal of Pharmaceutical Sciences, 55, 1-11. https://doi.org/10.1590/s2175-97902019000217249

7. Das R, Romi W, Das R, Sharma HK and Thakur D (2018). Antimicrobial potentiality of actinobacteria isolated from two microbiologically unexplored forest ecosystems of Northeast India. BMC Microbiology, 18(1). https://doi.org/10.1186/s12866-018-1215-7

8. Dhakal D, Pokhrel AR, Shrestha B and Sohng JK (2017). Marine rare actinobacteria: Isolation, characterization, and strategies for harnessing bioactive compounds. Front. Microbiol., 8, 1106. 
9. El-Naggar NE, El-Bindary AA, Abdel-Mogib M and Nour NS (2017). In vitro activity, extraction, separation and structure elucidation of antibiotic produced by Streptomyces anulatus NEAE-94 active against multi-drug resistant Staphylococcus aureus, Biotechnology \&Biotechnological Equipment, 31:2, 418-430, DOI: https://doi.org/10.1080/13102818.2016.1276412

10. Fiedler Forsyth MP, Shindler DB, Gochnauer MB and Kushner DJ (1971). Salt tolerance of intertidal marine bacteria. Can J Microbiol 17:825-828.

11. Garrity GM, Bell JA and Lilburn TG (2004). Taxonomic outline of the prokaryotes. Bergey's manual of systematic bacteriology. New York.

12. Girija S, Veeramuthu D, Pandi Suba K, Hariprasad G and Raghuraman R (2014). Chromatographic characterization and GC-MS evaluation of the bioactive constituents with antimicrobial potential from the pigmented ink of Loligo duvauceli. Int Sch Res Notices. doi:10.1155/2014/820745

13. Hassanshahian M and Mohamadian J (2011). Isolation and characterization of Halobacterium in Iran. Jundishapur J Microbiol 4:S59-S65.

14. Kumar N, Singh RK, Mishra SK, Singh AK and Pachouri UC (2010). Isolation and screening of soil Actinomycetes as source of antibiotics active against bacteria. International Journal of Microbiology Research, Volume 2, Issue 2, pp-12-16, ISSN: 0975-5276.

15. Kumar PS, Duraipandiyan V and Ignacimuthu S (2014). Isolation, screening and partial purification of antimicrobial antibiotics from soil Streptomyces sp. SCA 7. Kaohsiung Journal of Medical Sciences, 30 (9): 435-446.

16. Kumar S, Stecher G, Li M, Knyaz C and Tamura K (2018). MEGA X: Molecular Evolutionary Genetics Analysis across Computing Platforms. Mol. Biol. Evol., 35, 1547-1549.

17. Litzner BR, Caton TM and Schneegurt MA (2006). Carbon substrate utilization, antibiotic sensitivity, and numerical taxonomy of bacterial isolates from the Great Salt Plains of Oklahoma. Arch Microbiol 185:286-296

18. Nandhini SU, Sangareshwari S and Lata K (2015). Gas chromatography-mass spectrometry analysis of bioactive constituents from the marine Streptomyces. Asian J Pharm Clin Res 8:244246

19. Nazemi M, Khoshkhoo Z, Motalebi A and Karim H (2010). Identification non polar component and antibacterial activities of Iophonla evistylus from Persian Gulf. Int J Environ Sci Te 6:92-197

20. Newman DJ and Cragg GM (2016). Natural Products as sources of new drugs from 1981 to 2014. J. Nat. Prod., 79, 629-661.

21. Nithya TG, Jayanthi J and Raghunathan MG (1972). Phytochemical, Antibacterial and GC MS analysis of a floating fern Salvinia molesta D.S.Mitchell, International Journal of PharmTech Research, 2015, Vol.8, No.9, pp 85-90. 
22. O'Neill J (2016). Tackling drug-resistant infections globally: final report and recommendations [Internet]. London (UK): The review on antimicrobial resistance; [cited 2018 May 8]. Available from https://amr-review.org/sites/default/files/160525_Final\%20paper_with\%20cover.pdf

23. Patel AB, Mahala K, Jain K and Madamwar D (2018). Development of mixed bacterial cultures DAK11 capable for degrading mixture of polycyclic aromatic hydrocarbons (PAHs). Bioresour. Technol., 288- 296.

24. Rahbar N, Shafagha A and Salimi F (2012). Antimicrobial activity and constituents of the hexane extracts from leaf and stem of Origanum vulgare L. sp. Viride (Boiss.) Hayek. Growing wild in Northwest Iran. J Med Plants Res 6:2681-2685. doi:10.5897/ JMPR11.1768

25. Roy RN, Laskar S and Sen SK (2006). Dibutyl phthalate, the bioactive compound produced by Streptomyces albidoflavus 321.2. Microbiol Res.;161:121-6.

26. Sermakkani M and Thangapandian V (2012). GC-MS analysis of Eassiaitalica leaf methanol extract. Asian J Pharm Clin Res.;5:90-94.

27. Subramani R and Aalbersberg W (2013). Culturable rare actinomycetes: Diversity, isolation and marine natural product discovery. Appl. Microbiol. Biotechnol., 97, 9291-9321.

28. Subramani R and Sipkema D (2019). Marine Rare Actinomycetes: A Promising Source of Structurally Diverse and Unique Novel Natural Products. Mar. Drugs, 17, 249. doi: https://www.mdpi.com/1660-3397/17/5/249

29. Vaijayanthi G, Vijayakumar R and Dhanasekaran D (2016). 'Actinobacteria - A Biofactory of Novel Enzymes', in Actinobacteria-Basics and Biotechnological Applications, eds D. Dhanasekaran, and Y. Jiang, (Norderstedt: BoD), 88-111.

30. WHO (2017). Global priority list of antibiotic-resistant bacteria to guide research, discovery, and development of new antibiotics [Internet]. Geneva (Switzerland): World Health Organization; [cited 2018 May 8]. Available from http://www.who.int/medicines/publications/WHO-PPLShort Summary 25Feb-ET NM WHO.pdf?ua=1

31. Yogeswari S, Ramalakshmi S, Neelavathy R and Muthumary J (2012). Identification and comparative studies of different volatile fractions from Monochaetia kansensis by GCMS. Glob J Phar- macol 6:65-71

32. Zhang H, Hua Y, Chen J, Li X, Bai X and Wang H (2018). Organism-derived phthalate derivatives as bioactive natural products. J Environ Sci Heal C 36:125-144. https://doi.org/10.1080/10590501.2018.1490512 
TABLES

\begin{tabular}{|c|l|}
\hline Table No. & Table Title \\
\hline 1. & Biochemical characteristics of Nocardiopsis_sp. Al-H10-1 \\
\hline 2. & GC-MS analysis of Nocardiopsis_sp. Al-H10-1 ethyl acetate extract \\
\hline
\end{tabular}

Table 1: Biochemical characteristics of Nocardiopsis_sp. Al-H10-1

\begin{tabular}{|l|c|}
\hline Biochemical Test & Result \\
\hline Methyl red test & - \\
\hline Voges-Proskauer test & - \\
\hline Indole production & - \\
\hline Urease test & - \\
\hline Nitrate reduction test & + \\
\hline Ammonia production test & + \\
\hline Catalase test & - \\
\hline H 2 production test & + \\
\hline Citrate utilization test & + \\
\hline TSI & + \\
\hline Gelatin hydrolysis test & + \\
\hline Casein hydrolysis test & + \\
\hline Starch hydrolysis test & + \\
\hline Utilization of Carbohydrates & + \\
\hline Mannitol & + \\
\hline Sucrose & + \\
\hline Xylose & + \\
\hline Glucose & + \\
\hline Maltose & + \\
\hline
\end{tabular}




\begin{tabular}{|l|c|}
\hline Lactose & - \\
\hline Antibiotic Susceptibility Test \\
\hline Antibiotic (Concentration) & Zone of Inhibition (mm) \\
\hline Kanamycin $(30 \mu \mathrm{g})$ & $7(\mathrm{~S})$ \\
\hline Streptomycin $(10 \mu \mathrm{g})$ & $21(\mathrm{~S})$ \\
\hline Nalidixic acid (30 $\mu \mathrm{g})$ & $0(\mathrm{R})$ \\
\hline Gentamicin $(10 \mu \mathrm{g})$ & $22(\mathrm{~S})$ \\
\hline Rifampicin $(5 \mu \mathrm{g})$ & $32(\mathrm{~S})$ \\
\hline Ciprofloxacin $(5 \mu \mathrm{g})$ & $23(\mathrm{~S})$ \\
\hline Ampicillin $(10 \mu \mathrm{g})$ & $0(\mathrm{R})$ \\
\hline Polymyxin-13 $(300 \mathrm{units} / \mathrm{disc})$ & $1(\mathrm{~S})$ \\
\hline Tetracycline $(30 \mu \mathrm{g})$ & $18(\mathrm{~S})$ \\
\hline Chloramphenicol (30 $\mu \mathrm{g})$ & $22(\mathrm{~S})$ \\
\hline Vancomycin $(30 \mu \mathrm{g})$ & $28(\mathrm{~S})$ \\
\hline Methicillin $(5 \mu \mathrm{g})$ & $0(\mathrm{R})$ \\
\hline Penicillin $(10 \mathrm{units} / \mathrm{disc})$ & $5(\mathrm{~S})$ \\
\hline
\end{tabular}


Table 2: GC-MS analysis of Nocardiopsis_sp. Al-H10-1 ethyl acetate extract

\begin{tabular}{|c|c|c|c|c|c|c|c|}
\hline $\begin{array}{l}\text { Peak } \\
\text { No. }\end{array}$ & $\begin{array}{l}\text { Retention } \\
\text { Time }\end{array}$ & Name of the Compound & $\begin{array}{l}\text { Molecular } \\
\text { Formula }\end{array}$ & $\begin{array}{l}\text { Molecular } \\
\text { Weight }\end{array}$ & $\begin{array}{l}\text { Peak } \\
\text { Area \% }\end{array}$ & Activity & Reference \\
\hline 1 & 8.045 & Dodecane, 2-methyl- & $\mathrm{C}_{13} \mathrm{H}_{28}$ & 184.36 & 2.42 & & \\
\hline 2 & 8.290 & Tetradecane & $\mathrm{C}_{14} \mathrm{H}_{30}$ & 198.39 & 2.99 & Antimicrobial & Girija S et. al., 2014 \\
\hline 3 & 8.471 & 2,4-bis(1,1-dimethylethyl)- Phenol & $\mathrm{C}_{14} \mathrm{H}_{22} \mathrm{O}$ & 206.32 & 3.84 & Antibacterial & $\begin{array}{l}\text { Nandhini SU et. al., 2015; } \\
\text { Yogeswari S et. al., } 2012\end{array}$ \\
\hline 4 & 8.602 & Pentadecane & $\mathrm{C}_{15} \mathrm{H}_{32}$ & 212.41 & 2.29 & Antimicrobial & Girija S et. al., 2014 \\
\hline 5 & 9.714 & Pentadecane & $\mathrm{C}_{15} \mathrm{H}_{32}$ & 212.41 & 3.37 & Antimicrobial & Girija S et. al., 2014 \\
\hline 6 & 9.978 & Heptadecane & $\mathrm{C}_{17} \mathrm{H}_{36}$ & 240.5 & 2.51 & Antimicrobial & Rahbar N et. al., 2012 \\
\hline 7 & 10.243 & Heptadecyl heptafluorobutyrate & $\mathrm{C}_{21} \mathrm{H}_{35} \mathrm{~F}_{7} \mathrm{O}_{2}$ & 452.5 & 2.51 & & \\
\hline 8 & 10.778 & Octadecane & $\mathrm{C}_{18} \mathrm{H}_{38}$ & 254.5 & 3.61 & Antibacterial & Nazemi M et. al., 2010 \\
\hline 9 & 10.979 & Heptadec-1-ene & $\mathrm{C}_{17} \mathrm{H}_{34}$ & 238.5 & 3.09 & & \\
\hline 10 & 11.149 & $\begin{array}{l}\text { Benzenepropanoic acid, 3,5-bis(1,1- } \\
\text { dimethylethyl-4-hydroxy-, methyl ester }\end{array}$ & $\mathrm{C}_{17} \mathrm{H}_{26} \mathrm{O}_{3}$ & 278.4 & 2.15 & & \\
\hline 11 & 11.260 & Dibutyl phthalate & $\mathrm{C}_{16} \mathrm{H}_{22} \mathrm{O}_{4}$ & 278.34 & 25.69 & Antimicrobial & $\begin{array}{l}\text { Roy RN et. al., 2006; Zhang } \\
\text { H et. al., } 2018\end{array}$ \\
\hline 12 & 11.901 & Heneicosane & $\mathrm{C}_{21} \mathrm{H}_{44}$ & 296.6 & 2.31 & Antimicrobial & Nandhini SU et. al., 2015 \\
\hline 13 & 12.109 & 8-methyl-Heptadecane & $\mathrm{C}_{18} \mathrm{H}_{38}$ & 254.5 & 1.48 & & \\
\hline 14 & 12.407 & Pentatriacontane & $\mathrm{C}_{35} \mathrm{H}_{72}$ & 492.9 & 2.62 & Antibacterial & Nithya TG et. al., 1972 \\
\hline 15 & 18.716 & Squalene & $\mathrm{C}_{30} \mathrm{H}_{50}$ & 410.7 & 1.43 & Antibacterial & $\begin{array}{l}\text { Sermakkani M and } \\
\text { Thangapandian V, } 2012\end{array}$ \\
\hline 16 & 28.569 & Diethyl-heptoxy-octadecoxysilane & $\mathrm{C}_{29} \mathrm{H}_{62} \mathrm{O}_{2} \mathrm{Si}$ & 470.9 & 28.07 & & \\
\hline 17 & 31.916 & $\begin{array}{l}\text { Pentacyclo[19.3.1.1(3,7).1(9,13).1(15,1 } \\
\text { 9)]octa }\end{array}$ & $\mathrm{C}_{40} \mathrm{H}_{48} \mathrm{O}_{4}$ & 592.8 & 9.60 & & \\
\hline
\end{tabular}




\section{FIGURE CAPTIONS}

358 Fig 1 Neighbor-joining tree of the strains and representative species of the genus Nocardiopsis and Streptomyces

359 based on nearly complete 16S rRNA gene sequences. Numbers at the nodes indicate the levels of bootstrap support

360 based on 1000 resampled data sets. The scale bar indicates 0.01 substitution per nucleotide position.

361 Fig 2 Antibacterial activity of Nocardiopsis_sp. Al-H10-1 isolate against various test organisms; blue bar (Colony

362 diameter, $\mathrm{mm}$ ), Green bar (Zone diameter, $\mathrm{mm}$ )

363 Fig 3 Effect of starch concentrations on growth and antimicrobial compounds production by Nocardiopsis_sp. Al-

364 H10-1 against Serratia marcescens

365 Fig 4 Effect of salt concentrations on growth and antimicrobial compounds production by Nocardiopsis_sp. Al-H10-

3661 against Serratia marcescens

367 Fig 5 Effect of $\mathrm{pH}$ on growth and antimicrobial compounds production by Nocardiopsis_sp. Al-H10-1 against

368 Serratia marcescens

369 Fig 6 GC-MS chromatogram of Nocardiopsis_sp. Al-H10-1 ethyl acetate extract

370

371 


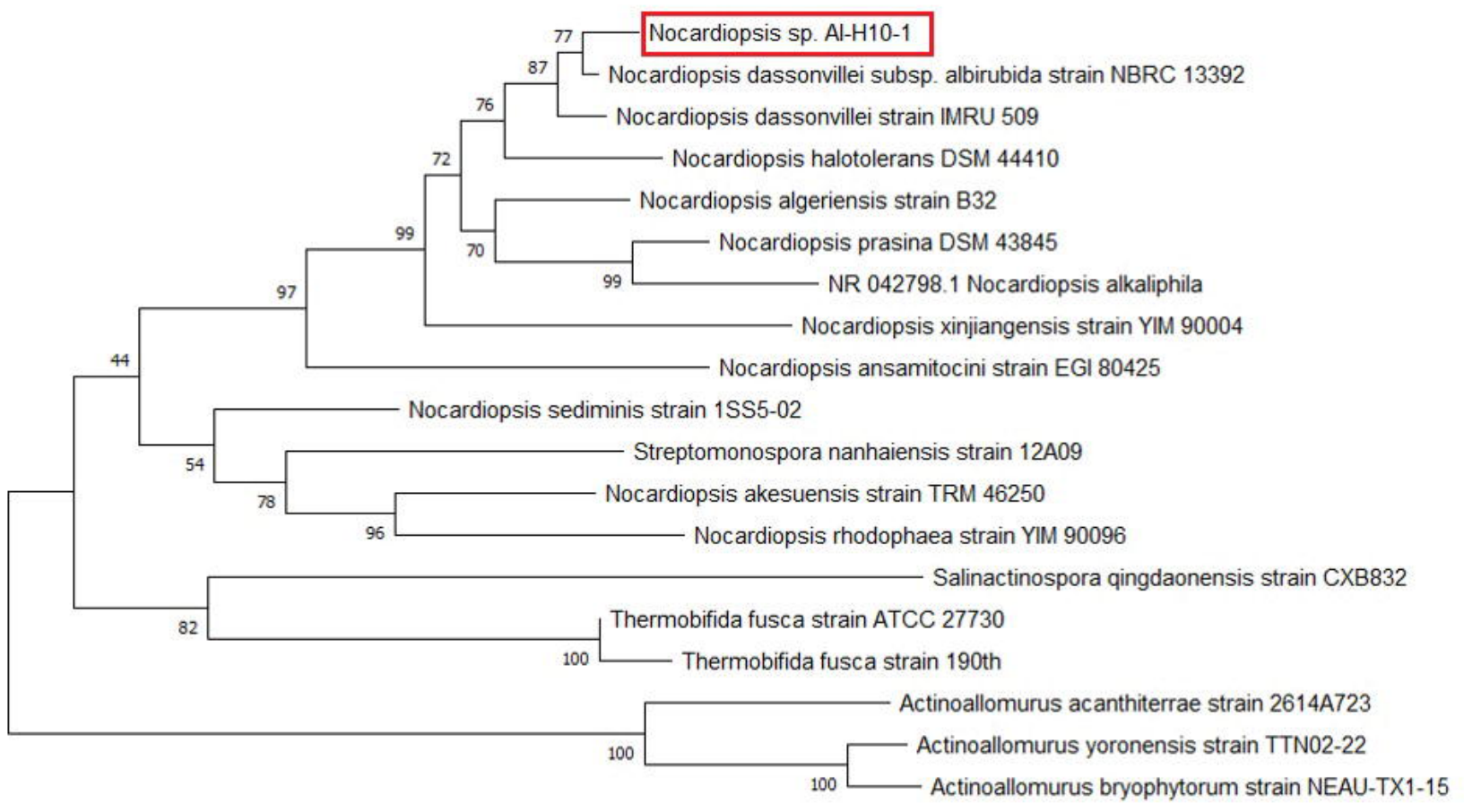




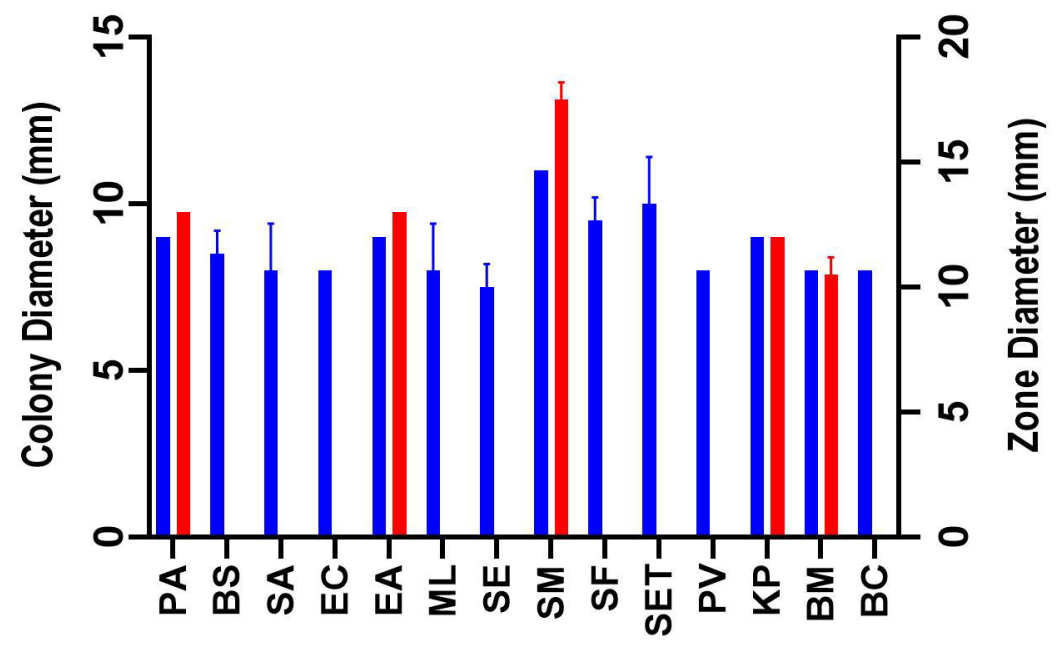

Test organisms 


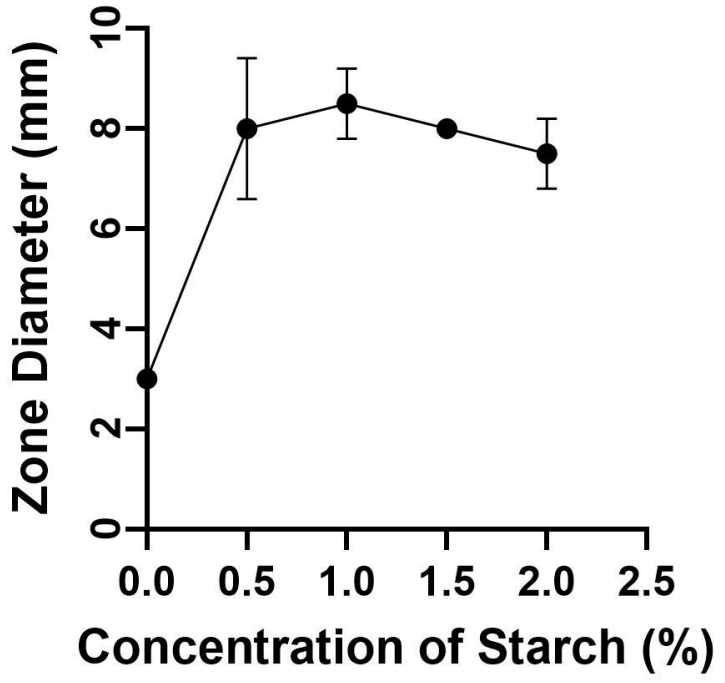




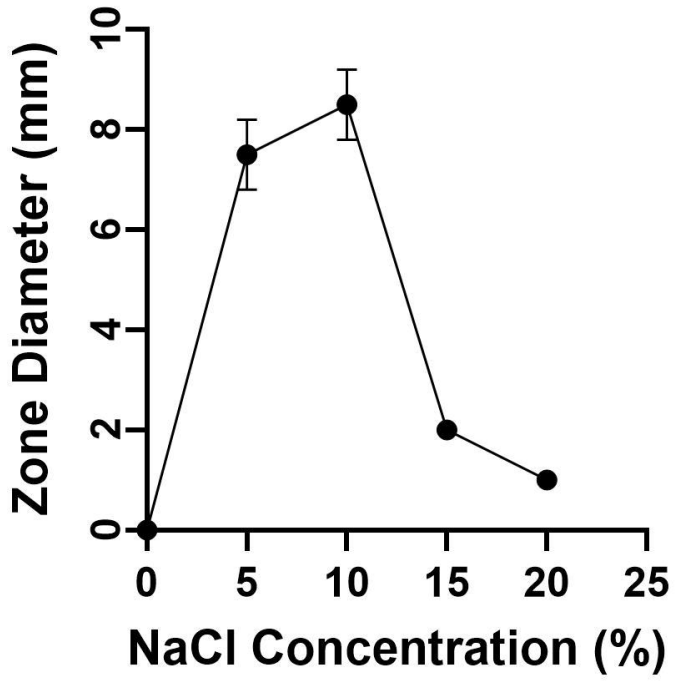




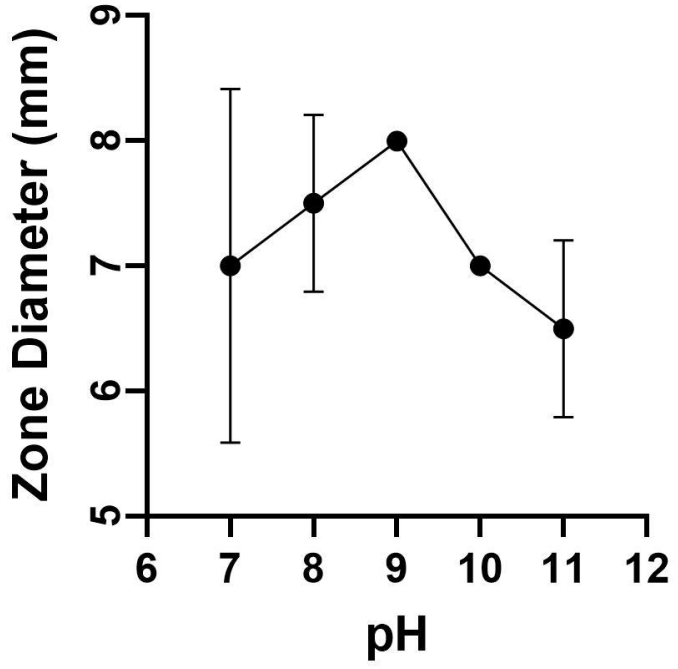


